\title{
ASPECTS CONCERNING FINANCIAL PROFITABLENESS ANALYSIS AND ITS PURPOSE IN SUBSTANTIATION OF FIRM'S STRATEGIC FINANCING DECISIONS
}

\author{
Solomon Daniela-Cristina, Lecturer \\ UNIVERSITY OF BACĂU \\ Dragomirescu Simona-Elena, Lecturer \\ UNIVERSITY OF BACĂU
}

\begin{abstract}
: enterprise in financing strategic decisions

The analysis of enterprise' performance by means of profitableness rates highlights the efficiency reports between a indicator of results (profit or loss) and an indicator that reflects an activity flux, (business number, consumed resources etc.) or a stock (own capital, total actives). The size of rates is influenced by accountancy policies and practices used by the enterprise that has different informational valences and reflects multiple sizes of economic-financial activity.
\end{abstract}

Financial profitableness, relevant indicator in enterprises performance appreciation and of its position on the market, depends on the commercial policy (commercial profitableness), on the engaged capital's efficiency (economic profitableness), on the policy and financial structure of enterprise (debt degree) offering information both to investors and managers, orienting the

The financial profitableness rate $(\boldsymbol{R} \boldsymbol{f})$ expresses the efficiency degree of using the own capitals. In the case where financial profitableness rate is bigger than the borrowed cost capital, then a supplementary value will be created to "payment of the shareholders' capitals (by the distributed dividends) and firm's self-financing (by the result in the reserve)" ${ }^{\prime 1}$.

The information given by the firm's yearly financial situations allow determination of financial profitableness rate. The relation calculation for this rate is the following ${ }^{2}$ :

\footnotetext{
S. Petrescu, Analysis and financial-accountancy diagnostic. Theoretical-practical guide, Second revised edition, CECCAR's Publish house, Bucharest, 2008, p. 238.

Gheorghe Vâlceanu, Vasile Robu, Nicolae Georgescu, Economic-financial analysis, Economic Publish house, Bucharest 2004, p.283.
}

$$
\mathbf{R}_{\mathbf{f}}=\frac{\text { Net profit }}{\text { Own capital }} \cdot 100
$$

In Anglo-Saxon terminology, the financial profitableness rate corresponds to the notion of Return on Equity (ROE) being calculated as below ${ }^{3}$ :

$$
\mathbf{R O E}=\frac{\text { Net income }}{\text { Average owner'equity }}
$$

Financial profitableness reflects the final purpose of an enterprise's shareholders, expressed by remuneration rate of capital investment made by them in providing enterprise's stockings or in reinvesting total/partial profit that reverts ${ }^{4}$.

The financial profitableness rate's analysis allows the establishing of determining factors and the identifying of some significant aspects for appreciating the enterprise's performance.

In specific literature ${ }^{5}$ few patterns of factorial analysis are known for financial profitableness rate:

$$
1 . \mathbf{R f}=\frac{\text { Net profit }}{\text { Total assets }} \cdot \frac{\text { Total assets }}{\text { Own capital }} \cdot 100
$$

\footnotetext{
3 Marshall D. H., McManus W., Viele D. F., „Accounting: what the numbers means", Seventh Edition, Ed. McGraw-Hill/Irwin, 2007, p. 77.

${ }^{4}$ Spãtaru, L., Economic-financial enterprise's analysis -Instrument of enterprise's management, Economic Publish house, Bucharest, p. 393.

5 W. Păvăloaia, D. Păvăloaia, Economic-financial analysis Concepts. Studies, Moldavia Publish house, Bacău, 2003, p. 310-311.
} 
$\frac{\text { Net profit }}{\text { Total assets }}=$ global capital enterprise's

profitableness invested in fixe and circular assets.

$\frac{\text { Total assets }}{\text { Own capital }}=$ multiplication factor of own

average capital or the arm of the financial lever that characterizes indirectly the debt degree of enterprise $\left(\mathrm{g}_{\hat{1}}\right)$.

Because Total assets $=$ Own capital + Debts , the relation becomes:

$$
\begin{aligned}
& \frac{\text { Total assets }}{\text { Own capital }}=\frac{\text { Own capital }+ \text { Debts }}{\text { Own capital }} \Rightarrow \\
& \frac{\text { Total assets }}{\text { Own capital }}=1+\frac{\text { Debts }}{\text { Own capital }}
\end{aligned}
$$

The financial profitableness rate depend on the permanent capitals structure, meaning on the proportion existent between the borrowed capital, respective debts and own capital .

$$
\text { The } \frac{\text { Debts }}{\text { Own capital }} \text { report is a quotient }
$$

named "financial lever" that influences the financial profitableness rate and that expresses the enterprise's debt degree, report that generates the appearance of financial efficiency increase or the financial lever effect. The effect of lever's increase may be both in favor and unsafe, on this effect the financial risk being connected, the one flowing from capital cost that assures the financing.

According to this pattern, the increase of financial profitableness rate can be realized through:

- increase of net profit to a leu assets and

- growth of debt degree if economical profitableness is higher than interest rate.

A growth of multiplication factor can be appreciated as favorable, but it should be reminded that this indicator reflects the debt degree, and therefore is necessary the framing of the size of the multiplication factor under certain preordained optimal values.

\section{Rf}

$=\frac{\text { Net profit }}{\text { Turnover }} \cdot \frac{\text { Turnover }}{\text { Total assets }} \cdot \frac{\text { Total assets }}{\text { Own capital }} \cdot 100$

The financial profitableness rate represents the product between the commercial profitableness rate (profit's net average), assets rotation and global debt rate.

The increase of the financial profitableness rate of own capital is the consequence of the invested capital efficiency increase, as a consequence of the increase of the assets' speed's rotation with direct implications on the volume of sells on invested monetary unit but also because of the profit increase to a leu business number that reflects the efficiency of exploitation activity.

According to this pattern the increase of financial profitableness may be realized if the following conditions are satisfied:

a). $I_{\text {Net profit }}>I_{\text {Turnover }}$ - the increase of gross profit in an superior rhythm to turnover, possible to be realized through:

- reduction of exploitation expenses;

- increase of physical volume of physical production and of the delivered one;

- manners of amortization calculation;

- fiscal state's policy.

b). $\mathrm{I}_{\text {Turnover }}>\mathrm{I}_{\text {Total assets }}$ - the increase of turnover will outmatch the total assets growth aspect that means the increase of the enterprise's speed rotation assets.

c). $\mathrm{Re}>\mathrm{d}$ economical profitableness (Re) will outmatch the interest rate(d).

By its calculation pattern the financial profitableness rate also highlights the following specific conditions:

$\checkmark$ financial profitableness is influenced by the modality of providing capitals, reason for which is sensitive as against financial structure, meaning the debt degree of the enterprise,

$\checkmark$ the size of gross profit is influenced by tax evolution, elements undeductive from a fiscal point of view and of the fiscal deductions,

the financial profitableness rate should be higher than the average tax rate in order to make the enterprise's actions more attractive. Under this situation, for the 
enterprise, is more advantageous to make appeal to medium and long term loaning for activity financing, this assuring in this way a supplementary profit. The use of the debt should be very carefully made in order not to limit the financial independence of the firm and to reduce the supplementary debt possibilities in crisis periods.

The data necessary for analyzing the financial profitableness rate for S.C. ALFA S.A. are presented in table nr. 1 :

Table nr. 1 Indicators concerning the financial profitableness rate's analysis for S.C. ALFA S.A.

\begin{tabular}{|l|r|r|r|r|}
\hline \multicolumn{1}{|c}{ Indicator's name } & \multicolumn{1}{c}{ MU } & \multicolumn{1}{c|}{31.12 .2005} & 31.12 .2006 & 31.12 .2007 \\
\hline Net profit & \multicolumn{1}{c|}{ lei } & 125.457 & 324.568 & 257.005 \\
\hline Own capital & lei & 508.077 & 2.059 .013 & 2.049 .572 \\
\hline Financial profitableness rate (Rf) & $\mathbf{\%}$ & $\mathbf{2 4 , 6 9}$ & $\mathbf{1 5 , 7 6}$ & $\mathbf{1 2 , 5 4}$ \\
\hline The variation of financial profitableness rate & $\%$ & 0 & $-8,93$ & $-3,22$ \\
\hline Growth index Rf & $\mathbf{\%}$ & $\mathbf{1 0 0}$ & $\mathbf{6 3 , 8 3}$ & $\mathbf{7 9 , 5 7}$ \\
\hline Growth index net profit & $\%$ & 100 & 258,71 & 79,18 \\
\hline Growth index own capital & $\%$ & 100 & 405,26 & 99,54 \\
\hline Informative value & $\%$ & $25 \%$ & $25 \%$ & $25 \%$ \\
\hline Total assets & lei & 837.352 & 2.746 .266 & 3.007 .678 \\
\hline $\begin{array}{l}\text { Global profitableness of invested capitals } \\
\text { (Net profit/Total assets) }\end{array}$ & $\%$ & $14,98 \%$ & $11,82 \%$ & $8,54 \%$ \\
\hline Debt degree (Total assets/Own capital) & - & 1,65 & 1,33 & 1,47 \\
\hline Turnover & lei & 224.748 & 234.798 & 197.000 \\
\hline Net profit average (Net profit/Turnover) & - & 0,56 & 1,38 & 1,30 \\
\hline The assets' speed rotation (Turnover/Total assets) & - & 0,27 & 0,09 & 0,07 \\
\hline
\end{tabular}

The evolution of financial profitableness rate for S.C.ALFA S.A is presented in figure nr. 1.

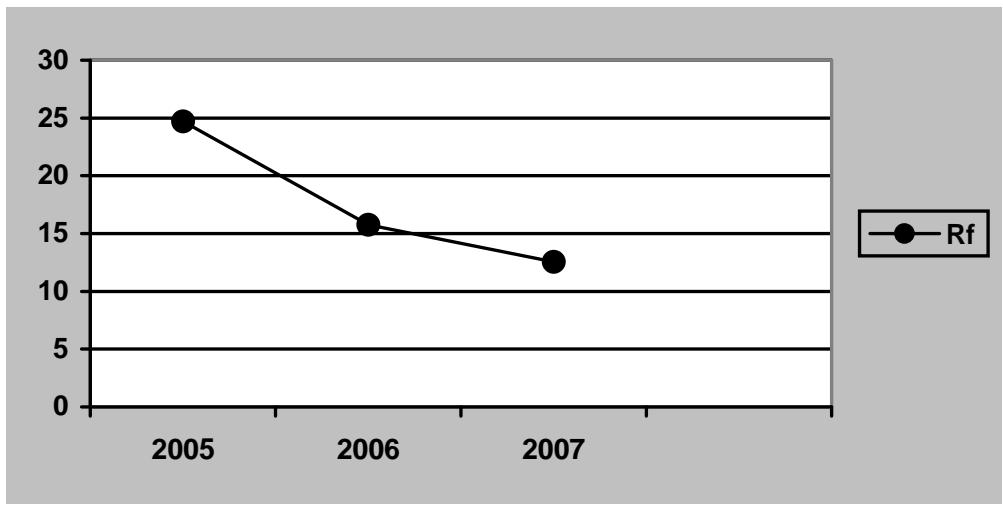

Figure 1 The evolution of financial profitableness rate for S.C.ALFA S.A

The financial profitableness rate for the analyzed period manifested a decreased tendency that is equivalent to a weak net wining remuneration of own resources, respective the decrease of the own capitals capacity of creating net profit.
During 2007 the rate's level was of $12,54 \%$ that means that for 100 lei own capitals revert 12,54 lei net profit. This level does not assure the reconstruction of own capitals only for net profits.

The rate's modification $\Delta \mathrm{Rf}=$ $3,22 \%$ was determined by: 
$\checkmark$ decrease of global invested capitals profitableness with $3,28 \%$ (from $11,82 \%$ to $8,54 \%$ ) that had a negative effect on the indicator;

the increase of firm's debt degree with 0,14 (from 1,33 to 1,47 ) with favorable effect upon financial profitableness rate that did not succeed the compensation of unfavorable effect that the decrease of global invested capitals rate in fixe and circular assets. Under these circumstances, for society, it is more advantageous to appeal to loaning on medium and long term for activity financing, assuring therefore a supplementary profit. The use of debt should be carefully made in order not to limit the financial firm's independence and to reduce the supplementary debt possibilities in crisis periods.

The financial profitableness rate constitutes a relevant indicator in appreciating the enterprise's position on the market. An increased remuneration of capitals assures a facile access to financial resources due to the present shareholders' trust of reinvesting in enterprise and of potential investors - owners of financial resources available for investments as well as the development capacity.

\section{References:}

[1] Marshall, D. H., McManus, W., Viele, D. F., Accounting: what the numbers means, Seventh Edition, Ed. McGraw-Hill/Irwin, 2007.

[2] Păvăloaia, W., Păvăloaia, D., Economic-financial analysis Concepts. Studies, Moldavia Publish house, Bacău, 2003.

[3] Petcu M., The enterprise's economic-financial analysis, Economic Publish house, Bucharest, 2003.

[4] Petrescu, S., Analysis and financial-accountancy diagnostic. Theoretical-practical guide, Second revised edition, CECCAR's Publish house, Bucharest, 2008.

[5] Spãtaru, L., Economic-financial enterprise's analysis -Instrument of enterprise's management, Economic Publish house, Bucharest, 2004.

[6] Vâlceanu, Gh., Robu, V., Georgescu, N., Economic-financial analysis, Economic Publish house, Bucharest, 2004.

[7] *** Public Finances Minister's Command no. 1752/2005 for the approval of Accountancy Settlements according to European directives, published in Official Monitor, $1^{\text {st }}$ Part, no. 1080 from 30/11/2005. 